\title{
CHANGING HUMAN RESOURCE PRACTICES IN PURVIEW OF COVID-19 LOCKDOWN ON THE TEACHING AND NON-TEACHING STAFF ACROSS COLLEGES IN MUMBAI
}

\author{
Heer Amrish Jalundhwala \\ Assistant Professor, Laxmichand Golwala College of Commerce and Economics, \\ Ghatkopar (East), Mumbai, India \\ Email: heerjalu29@gmail.com
}

\begin{abstract}
With more than 28 lakh people infected worldwide and 1.97 lakh dead, the COVID-19 pandemic shows no signs of abating. Educators and students around the world are feeling the extraordinary ripple effect of the novel Coronavirus as schools and colleges shut down amid the public health emergency. While temporary school closures as a result of health and other crises are not new, unfortunately, the global scale and speed of the current educational disruption is unparalleled and if prolonged, could threaten the right to education. A multi-pronged strategy is necessary to manage the crisis and build a resilient Indian education system in the long term. While health officials scramble to get a grip on multiple outbreaks, the education institutes of Mumbai have left no stones unturned in order to continue imparting quality education to the students. The present study was undertaken to find the changing Human Resource practices in the purview of COVID-19 Lockdown on the Teaching and Non-Teaching staff across Colleges in Mumbai.
\end{abstract}

Key words: COVID-19, Commerce colleges, Lockdown, Teaching \& Non-teaching Staff.

\section{Introduction}

Modern technology is enabling professionals from the education sector to think out of the box, beyond the traditional classroom learning and explore the world of E-content and E-Learning by maximizing the use of online resources. E-content is a very powerful tool of education. E-content is valuable to the learners and also helpful to teachers of all individual instruction systems; E-content is the latest method of instruction that is used by professionals in the teaching sector. Education Teaching plays a vital role in the formal education system. In spite of established sound theories of teaching, it still continues to be a challenging task. Teaching-centre and group-oriented methods of instruction hardly provide for individual differences of the learners. E-learning is the new trend of education. The term covers a wide set of applications and processes, such as web-based learning, computer-based learning, virtual classrooms, and digital collaboration. Increased preservation, reduced learning time are other benefits to students.

As the days pass by with no immediate solution to stop the outbreak of COVID-19, school and university closures will not only have a short-term impact on the continuity of learning for more than 285 million young learners in India but also engender far-reaching economic and societal consequences. This has also impacted the smooth functioning of schools, colleges and universities across the globe thus hampering the learning process and day-to-day functioning of teaching and non-teaching staff along with the students. However, modern-day technology has made it possible to work from home rather than solely relying on "only working from office" practice which is now a thing of the past. Needless to say, the pandemic has transformed the centuries-old, chalk-talk teaching model to one driven by technology. Hence this study was undertaken to find the changing 
Human Resource practices in the purview of COVID-19 Lockdown on the Teaching and NonTeaching staff across Colleges in Mumbai.

\section{Literature Review}

Prime Minister of India, Shri Narendra Modi assessed the novel Corona Virus' impact on the Indian economy and the possibility of a second stimulus package to boost sectors hit hard by the pandemic. Several multilateral agencies, including the World Bank and the International Monetary Fund, have drastically cut their India GDP growth forecasts for 2020-21 after economic activity in the country halted due to the spread of the Coronavirus. Currently, school closures in over a dozen countries due to the COVID-19 outbreak have disrupted the education of at least 290.5 million students worldwide, according to the United Nations Educational, Scientific, and Cultural Organization. The National Policy on Education (1986) has emphasized the application of Educational Technology to Improve the Quality of Education at all levels. It has also laid special emphasis on using computers in the teaching-learning process. The rapid development in computer technology, together with the use of computers by teachers, paved the way for the introduction of computers in teaching and learning. With the advancement of technology, the computer has become more user friendly, so the teachers can attempt to develop E-content while working from home. The International Monetary Fund (IMF) has revised its global GDP growth estimate from $3.3 \%$ just 3 months ago to a contraction of $3 \%$, something not seen since the Great Depression of the 1930s. IMF says India will remain the 'fastest-growing major economy in 2020'. But one must remember that the COVID-19 onslaught is only at its initial phase. As the vaccine is yet to be found, lockdowns remain the only way to slow down its speed.

\section{Objectives of the Study}

1. To study the impact of lockdown due to COVID-19 pandemic on the teaching and nonteaching staff of Commerce colleges across Mumbai, India.

2. To study the effectiveness of changing Human Resource practices in the purview of Work from Home experience with regards to teaching and non-teaching staff of Commerce colleges across Mumbai.

\section{Research Methodology}

The research method used was 'Survey method', under which the information would be secured concerning the subject of study from a selected number of respondents of the concerned Universe.

\section{Problem Identification}

It is a Need-based project. The research is done for finding out the impact of COVID-19 on the teaching and non-teaching staff of Commerce colleges across Mumbai and to study the effectiveness of changing HR practices in the purview of work from home experience.

\section{Sample Size}

The total sample size was 90 .

\section{Data Collection}

Data collection was done through a self-prepared, structured questionnaire. The custom-designed questionnaire was sent across to the respondents with a request to answer the questions online and return the completely filled questionnaire.

\section{Primary Data}

The primary data was gathered by an online questionnaire. 


\section{Secondary Data}

For the purpose of understanding the topic in detail and putting the recommendations, findings from the Internet were used.

\section{Scope of the Study}

The scope of this research is limited to employees in the education sector (teaching and nonteaching staff) which is limited to Commerce colleges across Mumbai.

\section{Limitations of the Study}

- The most apparent limitation was that some facts and figures may not be exactly disclosed due to Organizational Rules, Regulations and Policies.

- Time factor: As the research study was conducted within a limited duration of time, a detailed study could not be made.

- This type of research is ideal for finding out numerical data. It would be more useful to conduct interviews and study the atmosphere within the organization. Unfortunately, that was not possible for this study, and therefore an online questionnaire was used.

- As the aspirations of humans change with time, they are very difficult to research. Therefore, the Organizational policies too need a careful framing up \& periodical review.

\section{Data Analysis and Interpretation}

The data collected were classified, tabulated \& analysed using Microsoft Excel and statistical method. The data is analysed to identify the issues.

Parameters: (1) Communication from the top management (2) Compensation (3) Employee Conditions and facilities (4) HR Systems \& Processes by the top management (5) Innovation \& Progression. The analysis of the Survey is as under:

\begin{tabular}{|l|c|}
\hline$\leq 60 \%$ & Areas of Concern \\
\hline$>60 \%-<80 \%$ & Alert \\
\hline$\geq 80 \%$ & Strength \\
\hline
\end{tabular}

\section{Findings}

\section{Communication from the Top Management}

The process by which individuals interact, Share and cooperate is called Communication. Internal communication channels are a key to make the employees feel well informed and belonged to whatever is happening in the organization.

\begin{tabular}{|l|c|c|}
\hline \multicolumn{1}{|c|}{ Communication } & Agree \% & Disagree \% \\
\hline I am aware of the pandemic and its effect on my job. & 90 & 10 \\
\hline I am well informed about the business decisions that impact my work. & 85 & 15 \\
\hline $\begin{array}{l}\text { Clarity regarding the Channels of communication (for example, Zoom } \\
\text { App, Google Hangouts) \& ideas to improve business processes \& } \\
\text { policies are there. }\end{array}$ & 79 & 21 \\
\hline The organisational policies are well-communicated at all levels. & 91 & 9 \\
\hline
\end{tabular}

\section{Compensation}

Monetary compensation is an employee's gross payroll pay rate and benefits program funded by an Organization or an Agency. In short, it means the remuneration paid to the employees \& the quality of other benefits offered by the organization. 


\begin{tabular}{|l|c|c|}
\hline \multicolumn{1}{|c|}{ Compensation } & Agree \% & Disagree \% \\
\hline Timely receipt of remuneration & 80 & 20 \\
\hline $\begin{array}{l}\text { Compensation practices in our firm in line with those being followed } \\
\text { in similar organizations }\end{array}$ & 65 & 35 \\
\hline $\begin{array}{l}\text { Total work offering, is comparable to other companies in similar } \\
\text { organizations }\end{array}$ & 67 & 33 \\
\hline $\begin{array}{l}\text { My Total Remuneration is equitable with what others in similar } \\
\text { positions are drawing in comparable organizations. }\end{array}$ & 65 & 35 \\
\hline
\end{tabular}

\section{Employee Conditions \& Facilities}

Employee conditions and facilities mean the right conditions \& resources required for carrying out a particular job.

\begin{tabular}{|l|c|c|}
\hline \multicolumn{1}{|c|}{ Employee Conditions \& Facilities } & Agree \% & Disagree \% \\
\hline $\begin{array}{l}\text { My Organization provides sufficient resources to do my job from } \\
\text { home (laptops, Internet connectivity) }\end{array}$ & 51 & 49 \\
\hline $\begin{array}{l}\text { My firm is well prepared in emergency situations for employee } \\
\text { safety. }\end{array}$ & 71 & 29 \\
\hline
\end{tabular}

\section{Human Resource Systems \& Processes by the Top Management}

Each Organization works towards the realization of one vision. It includes Human resource planning, Employee remuneration and Benefits, Administration, Performance Management and Employee Relations.

\begin{tabular}{|l|c|c|}
\hline \multicolumn{1}{|c|}{ HR Systems \& Processes } & Agree \% & Disagree \% \\
\hline $\begin{array}{l}\text { The top management processes enable fair assessment of the } \\
\text { employee's contribution at work. }\end{array}$ & 72 & 28 \\
\hline The HR systems in the Organization are employee-friendly. & 90 & 10 \\
\hline $\begin{array}{l}\text { I feel the organizational HR processes are in sync with industry } \\
\text { practices. }\end{array}$ & 80 & 20 \\
\hline
\end{tabular}

\section{Innovation \& Progression}

In today's competitive environment Organizations must foster innovation and progression and manage change successfully.

\begin{tabular}{|l|c|c|}
\hline \multicolumn{1}{|c|}{ Innovation \& Progression } & Agree \% & Disagree \% \\
\hline $\begin{array}{l}\text { I am encouraged to think differently \& focus on improving } \\
\text { processes \& systems (by introducing online lectures, preparing } \\
\text { presentations, E-content and E-learning resources for the students) }\end{array}$ & 89 & 11 \\
\hline $\begin{array}{l}\text { My seniors support innovative ideas suggested by me for } \\
\text { accomplishing business results. }\end{array}$ & 90 & 10 \\
\hline
\end{tabular}

\section{Results}

(A) Strengths: (Includes the Parameters which have the Satisfaction Score above $80 \%$ )

- $\quad$ Communication: satisfaction score $86.25 \%$.

- HR Systems \& Processes: satisfaction score $80.67 \%$.

- Innovation \& Progression: satisfaction score $89.5 \%$.

(B) Areas of Improvement: (Includes the Parameters which have the Satisfaction Score between $60 \& 80 \%)$

- $\quad$ Employee Compensation: satisfaction score $69.25 \%$. 
- $\quad$ Employee conditions \& facilities: satisfaction score $61 \%$.

(C) Areas of Concern: (Includes the Parameters which have the Satisfaction Score $\leq 60 \%$ )

- None of the Parameters scored $\leq 60 \%$.

\section{Conclusions \& Suggestions}

The actions that educational institutes need to take into account are as follows:

1. Demonstrate to employees that the organization cares about them, wants them to advance in their careers and will help them satisfy their needs for personal growth.

2. Frame the compensation plan in such a way that it is equitable with other organizations.

3. Provide training courses for the staff (both teaching and nonteaching) by encouraging them to register for more online courses attend more workshops and familiarize them with the latest technology.

4. Arrangements should be made to provide employees with the necessary resources like laptops, internet connectivity, etc. like multinational companies since education is a vital sector for our economy.

5. Communication can be made more efficient by organizing virtual meeting at least once every week so that proper feedback system is enabled and to ensure that all the processes are on time.

6. Open-source digital learning solutions and Learning Management Software should be adopted so teachers can conduct teaching online. The DIKSHA platform, with reach across all states in India, can be further strengthened to ensure accessibility of learning.

7. Inclusive learning solutions, especially for the most vulnerable and marginalized, need to be developed. With a rapid increase of mobile internet users in India, which is expected to reach $85 \%$ households by 2024 , technology is enabling ubiquitous access and personalization of education even in the remotest parts of the country. This can change the schooling system and increase the effectiveness of learning and teaching, giving students and teachers multiple options to choose from. Many aspirational districts have initiated innovative, mobile-based learning models for effective delivery of education, which can be adopted by others.

8. It is also important to reconsider the current delivery and pedagogical methods in school and higher education by seamlessly integrating classroom learning with e-learning modes to build a unified learning system.

9. Indian traditional knowledge is well known across the globe for its scientific innovations, values, and benefits to develop sustainably technologies and medicines. The courses on Indian traditional knowledge systems in the fields of yoga, Indian medicines, architecture, hydraulics, ethnobotany, metallurgy and agriculture should be integrated with a present-day mainstream university education to serve the larger cause of humanity.

\section{References}

1. https://www.jagranjosh.com/general-knowledge/what-is-the-impact-of-coronavirus-onindian-economy-1582870052-1

2. https://economictimes.indiatimes.com/wealth/personal-finance-news/impact-of-thecoronavirus-pandemic-on-the-world-economy-and-how-india-is-

placed/articleshow/75217253.cms

3. https://economictimes.indiatimes.com/wealth/personal-finance-news/impact-of-thecoronavirus-pandemic-on-the-world-economy-and-how-india-is-

placed/articleshow/75217253.cms?utm_source=contentofinterest\&utm_medium=text\&utm_ campaign=cppst

4. https://www.bloombergquint.com/business/pm-modi-reviews-coronavirus-impact-on-indianeconomy-second-stimulus-package-in-consideration 
5. https://abcnews.go.com/International/global-impact-coronaviruseducation/story?id=69411738

6. https://shodhganga.inflibnet.ac.in/bitstream/10603/36805/6/06_chapter\%201.pdf

7. https://en.wikipedia.org/wiki/Transformative_learning

8. https://en.wikipedia.org/wiki/Impact_of_the_2019\%E2\%80\%9320_coronavirus_pandemic_0 n_education 